\title{
Pengaruh Motivasi Belajar Dan Dukungan Sosial Terhadap Hasil Belajar Matematika Siswa Kelas VIII SMP Negeri 2 Kusambi
}

\author{
(The Effect Of Learning Motivation And Social Support On Mathematical Learning \\ Outcomes Of Class VIII Students Of SMP Negeri 2 Kusambi)
}

\author{
Siti Sarmiati ${ }^{1}$, Kadir ${ }^{2}$, Anwar Bey ${ }^{2}$, Utu Rahim $^{3}$ \\ ${ }^{1}$ Alumnus Jurusan Pendidikan Matematika FKIP Universitas Halu Oleo; Co-author: \\ sitisarmiati331@gmail.com \\ ${ }^{2}$ Dosen Pendidikan Matematika FKIP dan PPS Universitas Halu Oleo \\ ${ }^{3}$ Dosen Pendidikan Matematika FKIP Universitas Halu Oleo
}

\begin{abstract}
Abstrak: Penelitian ini bertujuan untuk: Menguji pengaruh motivasi belajar dan dukungan sosial terhadap hasil belajar matematika pada siswa kelas VIII SMP Negeri 2 Kusambi baik secara bersama-sama maupun terpisah. Penelitian ini merupakan penelitian ex-post facto pada siswa kelas VIII SMP Negeri 2 Kusambi. Data diperoleh dari instrumen angket motivasi belajar dan dukungan sosial serta dari data dokumen hasil belajar matematika siswa kelas VIII SMP Negeri 2 Kusambi. Berdasarkan hasil analisis data disimpulkan bahwa: (1) motivasi belajar siswa dalam kategori baik dan sangat baik sebanyak 34,78\% atau sebanyak 24 siswa dan yang kategori kurang sebanyak $65,22 \%$ atau sebanyak 45 siswa; (2) dukungan sosial siswa dalam kategori baik dan sangat baik sebanyak 33,33\% atau sebanyak 23 siswa dan yang kategori kurang sebanyak 66,67\% atau sebanyak 46 siswa; (3) Secara bersama-sama maupun terpisah motivasi belajar dan dukungan sosial berpengaruh terhadap hasil belajar matematika
\end{abstract}

Kata kunci: Motivasi Belajar, Dukungan Sosial, Hasil Belajar Matematika.

\begin{abstract}
This research aims to: Test the effect of learning motivation and social support on mathematics learning outcomes in class VIII of SMP Negeri 2 Kusambi both together and separately. This research is ex-post facto research in class VIII of SMP Negeri 2 Kusambi. Data were obtained from learning motivation questionnaire and social support instruments as well as from the data of the mathematics learning outcomes document class VIII of SMP Negeri 2 Kusambi. Based on the results of data analysis concluded that: (1) student learning motivation in good and very good categories as much as $34.78 \%$ or as many as 24 students and the less category is $65.22 \%$ or as many as 45 students; 2) social support of students in good and very good categories as much as $33.33 \%$ or as many as 23 students and in the less category as much as $66.67 \%$ or as many as 46 students; (3) Taken together or separately learning motivation and social support influence the learning outcomes of mathematics
\end{abstract}

Keywords: Learning Motivation, Social Support, Mathematics Learning Outcomes.

\section{PENDAHULUAN}

Matematika merupakan salah satu mata pelajaran yang termuat dalam kurikulum sekolah mulai dari SD sampai dengan SMA. Matematika perlu diberikan kepada siswa agar siswa memiliki kemampuan berpikir logis, analitis, sistematis, kritis, dan kreatif, serta kemampuan bekerjasama (BSNP, 2006: 139).

Proses pembelajaran matematika dikatakan berhasil apabila siswa mampu memahami dan menguasai konsep matematika yang diajarkan. Empat komponen penting yang berpengaruh bagi keberhasilan belajar matematika siswa, yaitu: bahan belajar, suasana belajar, media dan sumber belajar serta guru sebagai objek pembelajaran. Komponen tersebut sangat penting dalam proses belajar, sehingga melemahnya satu atau lebih komponen dapat mempengaruhi tercapainya tujuan belajar yang optimal.

Guru memegang peranan penting dalam proses belajar mengajar, karena 
guru merupakan orang yang secara langsung memberikan materi pelajaran kepada siswa, sehingga siswa merupakan kunci utama dalam keberhasilan belajar siswa. Dalam proses pembelajaran guru hendaknya mampu mengorganisasikan materi dan kegiatan pembelajaran sedemikian rupa, sehingga tercipta suasana pembelajaran yang inovatif dan menyenangkan. Guru juga harus mampu menerapkan metode mengajar yang tepat dan melibatkan siswa secara aktif dalam proses pembelajaran.

Siswa merupakan individu yang secara langsung melakukan proses pembelajaran, sehingga siswa harus dapat mengikuti kegiatan pembelajaran dengan aktif. Siswa harus mampu pula mengungkapkan gagasan-gagasan, serta mampu menyertakan segala aspek yang ada pada dirinya baik kecerdasan, minat, perhatian, motivasi, cara belajar dan disiplin belajar, sehingga akan mencapai hasil belajar yang memuaskan.

Berdasarkan observasi awal dan wawancara dengan guru matematika yang mengajar di kelas VIII SMP Negeri 2 Kusambi yang dilakukan penulis di SMP Negeri 2 Kusambi pada tanggal 24 Januari 2018, menunjukkan bahwa hasil belajar matematika siswa masih sangat rendah dan masih belum mencapai nilai Kriteria Ketuntasan Minimal (KKM) seperti yang diharapkan yaitu 65. Hal ini dapat dilihat dari nilai rata-rata hasil belajar kelas $\mathrm{VIII}_{1}$, $\mathrm{VIII}_{2}, \mathrm{VIII}_{3}$, berturut-turut adalah 46,29; 45,96; 48,51 atau dengan rata-rata kelas secara keseluruhan yaitu 46,92.

Hasil belajar siswa dipengaruhi oleh banyak faktor, yaitu faktor dari dalam diri siswa (internal) dan faktor yang datang dari luar diri siswa (eksternal). Faktor internal yang mempengaruhi hasil belajar siswa salah satunya adalah motivasi belajar. Sedangkan faktor eksternal yang mempengaruhi hasil belajar siswa salah satunya adalah dukungan sosial.

Belajar sangat diperlukan adanya motivasi dan hasil belajar akan menjadi optimal kalau ada motivasi. Makin tepat motivasi yang diberikan, akan makin berhasil pula pelajaran itu. Jadi motivasi akan senang tiasa menentukan intensitas usaha belajar bagi para siswa (Sardiman, 2016: 84-85). Untuk menumbuhkan motivasi belajar siswa tidaklah mudah. Rendahnya dukungan sosial keluarga juga merupakan salah satu faktor penyebab sulitnya menumbuhkan motivasi belajar. Orang tua dan guru merupakan pendidik bagi siswa karena intensitasnya bertemu setiap hari. Oleh karena itu orang tua dan guru perlu kerja sama untuk menumbuhkan motivasi belajar tersebut dengan cara memberikan dukungan untuk mereka.

Dukungan sosial bisa didapat tidak hanya dari satu orang saja, melainkan orang-orang yang ada disekitar atau orangorang yang menemani saat sedang bahagia dan sedih. Dukungan tersebut datang dari orang tua kita, guru, sahabat saat disekolah dan juga bermain, serta orang terdekat yang setiap hari berinteraksi satu sama lain. Dalam perkembangannya bergaul, teman sebaya juga mempengaruhi prestasi dalam belajarnya. Jika teman sebaya memberikan pengaruh yang negatif, maka seseorang itu pun akan ikut pada pengaruh buruk tersebut. Sebaliknya Jika teman sebaya memberikan pengaruh yang positif, maka seseorang itu pun akan ikut pada pengaruh positif tersebut. Tugas dan lingkungannya yang tidak mendukung juga bisa menjadi sumber permasalahan bagi siswa dan itu menimbulkan kurangnya motivasi dalam belajar siswa. Misalnya saja terlalu banyak tugas yang diberikan oleh guru, kelas yang kotor, guru yang tidak dapat menyampaikan mata pelajaran pada muridnya dengan baik, kelas tidak kondusif ketika kegiatan belajar mengajar, dan hal lain sebagainya. Hai ini juga membuat siswa malas untuk berangkat kesekolah. Apalagi untuk belajar dan mengejarkan tugas.

Pada aktivitas kehidupan manusia sehari-hari hampir tidak pernah dapat 
terlepas dari kegiatan belajar, baik ketika seseorang melaksanakan aktivitas sendiri, maupun di dalam suatu kelompok tertentu. Dipahami ataupun tidak dipahami, sesungguhnya sebagian besar aktivitas di dalam kehidupan sehari-hari kita merupakan kegiatan belajar. Menurut Hamzah dan Mohamad (2014: 138), belajar adalah suatu proses yang menghasilkan perubahan perilaku yang dilakukan dengan sengaja untuk memperoleh pengetahuan, kecakapan, dan pengalaman baru kearah yang lebih baik.

Jihad (2012: 1) mengungkapkan belajar adalah kegiatan berproses dan merupakan unsur yang sangat fundamental dalam penyelenggaraan jenis dan jenjang pendidikan, hal ini berarti keberhasilan pencapaian tujuan pendidikan sangat tergantung pada keberhasilan proses belajar siswa di sekolah dan lingkungan sekitarnya. Sedangkan Faturohman (2007: 6), belajar adalah sebuah proses perubahan di dalam kepribadian manusia dan perubahan tersebut ditampakkan dalam bentuk peningkatan kualitas dan kuantitas tingkah laku seperti peningkatan kecakapan, pengetahuan, sikap, kebiasaan, pemahaman, keterampilan, daya pikir, dan kemampuan-kemampuan yang lain.

Mengajar adalah suatu perbuatan yang memerlukan tanggung jawab moral yang cukup berat. Berhasilnya pendidikan pada siswa sangat bergantung pada pertanggung jawaban guru dalam melaksanakan tugasnya. Pengertian mengajar secara umum merupakan suatu kegiatan yang kompleks dan tidak hanya sekedar menyampaikan informasi dari guru kepada siswa, tetapi mengandung banyak tindakan yang harus dilakukan agar hasil belajar sesuai dengan yang diharapkan. Menurut Aunurrahman (2016: 34), mengajar diartikan sebagai suatu keadaan atau suatu aktivitas untuk menciptakan suatu situasi yang mampu mendorong siswa untuk belajar. Situasi ini tidak harus berupa transformasi pengetahuan dari guru kepada siswa saja, akan tetapi dapat dengan cara lain misalnya belajar melalui media pembelajaran yang sudah disediakan.

$$
\text { Aqib (2013: 67) juga }
$$

mengungkapkan mengajar adalah kemampuan mengondisikan situasi yang dapat dijadikan proses belajar bagi siswa. Oleh sebab itu, mengajar tidak harus terikat ruang/tempat atau waktu. Sedangkan menurut Alma (2009: 20), mengajar ialah segala upaya yang dilakukan dengan sengaja guna menciptakan proses belajar pada siswa dalam mencapai tujuan yang telah dirumuskan, maka jelas bahwa yang menjadi sasaran dari proses pengajaran itu ialah siswa belajar.

Hasil belajar dapat diukur melalui tes yang sering dikenal dengan tes prestasi belajar. Hasil belajar pada dasarnya adalah hasil akhir yang diharapkan dapat dicapai setelah seseorang belajar. Dalam proses belajar matematika, ada kegiatan utama yaitu belajar bagi peserta didik dan mengajar oleh guru. Peserta didik belajar karena ingin melihat peserta didik itu memperoleh hasil belajar yang baik. Untuk memperoleh hasil belajar, dilakukan evaluasi atau penilaian yang merupakan tindak lanjut atau cara untuk mengukur tingkat penguasaan siswa. Kemajuan prestasi belajar siswa tidak saja diukur dari tingkat penguasaan ilmu pengetahuan tetapi juga sikap dan keterampilan. Dengan demikian penilaian hasil belajar siswa mencakup segala hal yang dipelajari di sekolah, baik itu menyangkut pengetahuan, sikap dan keterampilan (Jihad, 2012: 15).

Motivasi belajar pada dasarnya merupakan bagian dari motivasi secara umum. Dalam kegiatan belajar mengajar dikenal adanya motivasi belajar yaitu yang ada dalam dunia pendidikan atau motivasi yang dimiliki peserta didik (siswa). 
Belajar sangat diperlukan adanya motivasi dan hasil belajar akan menjadi optimal kalau ada motivasi. Makin tepat motivasi yang diberikan, akan makin berhasil pula pelajaran itu. Jadi motivasi akan senang tiasa menentukan intensitas usaha belajar bagi para siswa (Sardiman, 2016: 84-85).

Siswa yang memiliki motivasi belajar akan nampak melalui kesungguhan untuk terlibat di dalam proses belajar, antara lain nampak melalui keaktifan bertanya, mengemukakan pendapat, menyimpulkan pelajaran, mencatat, membuat resume, mempraktekkan sesuatu, mengerjakan latihan-latihan dan evaluasi sesuai dengan tuntutan pembelajaran (Aunurrahman, 2016: 180). Sedangkan menurut Asmani (2009: 135), terdapat dua faktor yang membuat seseorang dapat termotivasi untuk belajar. Pertama, motivasi belajar berasal dari faktor internal yaitu Motivasi ini terbentuk karena kesadaran diri atas pemahaman betapa pentingnya belajar untuk mengembangkan dirinya dan bekal untuk menjalani kehidupan. Kedua, motivasi belajar dari faktor eksternal yaitu dapat berupa rangsangan dari orang lain, atau lingkungan sekitarnya yang dapat mempengaruhi psikologis orang yang bersangkutan.

Dukungan sosial (social support) adalah bentuk perhatian, penghargaan, semangat, penerimaan, maupun pertolongan dalam bentuk lainnya yang berasal dari orang yang memiliki hubungan sosial dekat, antara lain orang tua, saudara, anak, sahabat, teman maupun orang lain dengan tujuan membantu seseorang saat mengalami permasalahan.

Dukungan sosial adalah informasi atau umpan balik dari orang lain yang menunjukan bahwa seseorang dicintai dan diperhatikan,dihargai dan dihormati, dan dilibatkan dalam jaringan komunikasi dan kewajiban yang timbal balik (King, 2012: 226). Sedangkan menurut Apollo dan Cahyadi (2012: 261), dukungan sosial adalah tindakan yang bersifat membantu yang melibatkan emosi, pemberian informasi, bantuan instrument, dan penilaian positif pada individu dalam menghadapi permasalahanya. Menurut Johnson (1994: 472), dukungan sosial merupakan keberadaan orang lain yang dapat diandalkan untuk memberi bantuan, semangat, penerimaan dan perhatian, sehingga bisa meningkatkan kesejahteraan hidup bagi individu yang bersangkutan. Sedangkan menurut Isnawati dan Suhariadi (2013: 3), dukungan sosial memiliki efek yang positif pada kesehatan yang mungkin terlihat bahkan ketika tidak berada di bawah tekanan yang besar.

Purba (2007 : 82-83), mengungkapkan pada dasarnya ada lima jenis dukungan sosial, adalah sebagai berikut:

1. Dukungan Emosional (Emotional Support)

Dukungan emosi meliputi ungkapan rasa empati, kepedulian dan perhatian terhadap individu. Biasanya, dukungan ini diperoleh dari pasangan atau keluarga, seperti memberi pengertian terhadap masalah yang sedang dihadapi atau mendengarkan keluhannya.

2. Dukungan Penghargaan (Esteem Support)

Dukungan penghargaan terjadi melalui ungkapan positif dan penghargaan yang positif pada individu, dorongan untuk maju, atau persetujuan akan gagasan atau perasaan individu dan perbandingan yang posotif individu dengan orang lain. Biasanya dukungan ini diberikan oleh atasan atau rekan kerja.

3. Dukungan Instrumental atau konkrit Dukungan jenis ini meliputi bantuan secara langsung. Biasanya dukungan ini, lebih sering diberikan oleh teman atau rekan kerja, seperti bantuan untuk menyelesaikan tugas yang menumpuk atau meminjamkan uang atau lain-lain yang dibutuhkan individu.

4. Dukungan Informasi (Information Support) 
Dukungan jenis ini meliputi pemberian nasihat, saran atau umpan balik kepada individu. Dukungan ini, biasanya diperoleh dari sahabat, rekan kerja, atasan atau seorang professional seperti dokter atau psikolog.

5. Dukungan Jaringan Sosial (Network Support)

Dukungan jaringan dengan memberikan perasaan bahwa individu adalah anggota dari kelompok tertentu dan memiliki minat yang sama rasa

\section{METODE PENELITIAN}

Metode penelitian yang digunakan dalam penelitian ini adalah metode penelitian Ex-Post Facto. Penelitian dengan pendekatan Ex-Post Facto adalah penelitian yang mencari hubungan sebab akibat yang tidak dimanipulasi atau diberi perlakuan oleh peneliti. Pada penelitian ini peneliti tidak mengadakan kegiatan pembelajaran karena kegiatan pembelajaran telah dilakukan oleh guru bidang studi matematika yang mengajar di kelas VIII SMP Negeri 2 Kusambi.

Waktu dan tempat Penelitian ini dilaksanakan di SMP Negeri 2 Kusambi kebersamaan dengan anggota kelompok merupakan dukungan bagi individu yang bersangkutan.

Berdasarkan uraian diatas maka dilakukan penelitian ini dengan tujuan untuk menguji pengaruh motivasi belajar dan dukungan sosial terhadap hasil belajar matematika pada siswa kelas VIII SMP Negeri 2 Kusambi baik secara bersamasama maupun terpisah.

pada semester genap tahun ajaran 2017/2018. Populasi dalam penelitian ini adalah seluruh siswa kelas VIII di SMP Negeri 2 Kusambi yang berjumlah 69 orang yang terdiri dari 23 siswa kelas VIII 1,25 siswa kelas $\mathrm{VIII}_{2}$ dan 21 siswa kelas $\mathrm{VIII}_{3 .}$. Sampel pada penelitian ini yaitu seluruh siswa kelas VIII SMP Negeri 2 Kusambi yang berjumlah 69 0rang. Jadi, sampel pada penelitian ini adalah sama dengan populasi penelitian. Gambaran hubungan antara tiga variabel dalam penelitian ini dapat dilihat dalam desain penelitian sebagai berikut:

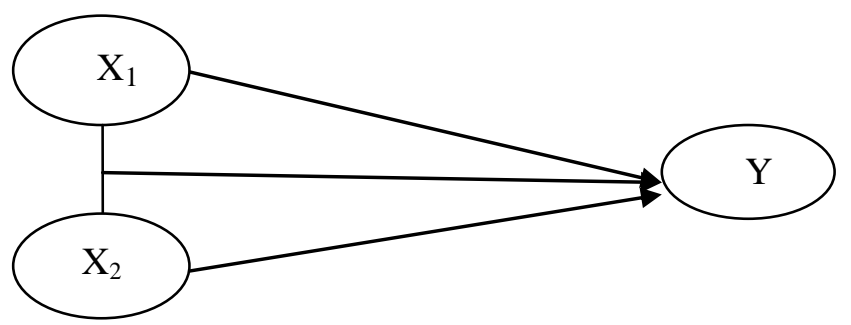

Gambar 1. Desain Penelitian

Keterangan : $\mathrm{X}_{1}=$ Motivasi Belajar, $\mathrm{X}_{2}=$ Dukungan Sosial dan $\mathrm{Y}=$ Hasil Belajar Matematika

Teknik pengumpulan data yang digunakan pada penelitian ini adalah:

1. Nilai ujian akhir semester genap tahun ajaran 2017/2018 yang didapatkan dari guru mata pelajaran setiap kelas yang dijadikan sampel penelitian.
2. Angket yang digunakan untuk mengetahui skala motivasi belajar dan dukungan sosial.

Teknik analisis data yang dilakukan pada penelitian ini diawali dengan menganalisis validitas dan reliabilitas hasil uji coba angket yang dilakukan pada 35 
responden yang berasal dari SMP Negeri 4 Kusambi. Selanjutnya analisis data dilakukan secara deskriptif dan inferensial. Analisis statistik deskriptif diperlukan untuk menggambarkan karakteristik distribusi masing-masing data variabel (motivasi belajar, dukungan sosial dan hasil belajar matematika) berupa mean,

\section{HASIL}

Uji coba instrument variabel motivasi belajar $\left(\mathrm{X}_{1}\right)$ dan dukungan sosial $\left(\mathrm{X}_{2}\right)$ dilakukan analisis validitas. Analisis validitas untuk masing-masing item intstrumen motivasi belajar menggunakan rumus korelasi product moment dan dibandingkan dengan $r_{\text {tabel }}$. Menggunakan $r_{\text {tabel }}$ dengan $n=69$ dan $\propto=5 \%$ maka $r_{\text {tabel }}$ $=0,333$. Pada hasil analisis menunjukkan bahwa dari 30 item instrument terdapat 26 item valid dan 4 item tidak valid. Analisis modus, nilai minimum, nilai maksimum dan standar deviasi. Analisis inferensial dalam penelitian ini dilakukan dengan menggunakan uji regresi linear berganda. Sebelum melakukan analisis inferensial terlebih dahulu dilakukan uji prasyarat analisis.

reliabilitas data uji coba instrumen motivasi belajar dan dukungan sosial menggunakan rumus Alpha. reliabilitas instrumen motivasi belajar diperoleh sebesar $0,871>0,400$ maka angket motivasi belajar sangat reliabel. reliabilitas instrumen dukungan sosial diperoleh sebesar $0,898>0,400$ maka angket dukungan sosial sangat reliabel.

Tabel 1. Analisis Deskriptif Motivasi Belajar, Dukungan Sosial dan Hasil Belajar Matematika

\begin{tabular}{lccc}
\hline \multicolumn{1}{c}{ Statistika } & $\mathbf{X}_{\mathbf{1}}$ & $\mathbf{X}_{\mathbf{2}}$ & $\mathbf{Y}$ \\
\hline Mean & 94.94 & 82.42 & 73.78 \\
Standar deviasi & 10.437 & 14.108 & 8.781 \\
Varians & 108.938 & 199.041 & 77.114 \\
Minimum & 71 & 45 & 45 \\
Maximum & 115 & 115 & 92 \\
\hline
\end{tabular}

Uji normalitas pada penelitian ini menggunakan rumus kolmogrov-sminorv, bahwa harga kolmogrov-smirnov untuk variabel motivasi belajar diperoleh hasil $0,0600<D_{\text {tabel }}=0,1637$ pada $\propto=0,05$. Untuk variabel dukungan sosial diperoleh harga kolmogrov-smirnov sebesar 0,0908 $<\mathrm{D}_{\text {tabel }}=0,1637$ pada $\propto=0,05$ serta hasil belajar matematika siswa diperoleh harga kolmogrov-smirnov sebesar 0,0876 < $\mathrm{D}_{\text {tabel }}=0,1637$ pada $\propto=0,05$. Dengan demikian data motivasi belajar, dukungan sosial, dan hasil belajar matematika siswa dalam penelitian ini berdistribusi normal. Hasil $\mathrm{D}_{\text {tabel }}$ diperoleh dari $\mathrm{D}_{\text {tabel }}=\frac{1,36}{\sqrt{n}}=$ $\frac{1,36}{\sqrt{69}}=0,1637$ dengan $\mathrm{n}=69$ dan taraf nyata $\propto=0,05$, karena $D_{\text {maks }}<D_{\text {tabel }}$ maka data variabel $\mathrm{X}_{1}, \mathrm{X}_{2}$ dan $\mathrm{Y}$ berdistribusi normal.

Uji multikolinearitas adalah uji yang digunakan untuk mengetahui apakah antara variabel bebas yang terdapat dalam model regresi memiliki hubungan yang sempurna atau tidak. Model regresi yang bebas dari multikolinearitas memiliki nilai VIF dibawah 10 dan nilai tolerance diatas 0,1 . Berdasarkan hasil uji multikolinearitas diperoleh nilai VIF untuk variabel motivasi belajar dan dukungan sosial sebesar 1,047 sangat jauh dari 10 dan nilai tolerance 0,955 berada diatas 0,1 . Dengan demikian dalam model regresi tidak dapat multikolinearitas untuk lebih jelasnya dapat dilihat pada tabel 2 . 
Tabel 2. Uji Multikolinearitas

\begin{tabular}{|c|c|c|}
\hline \multirow[t]{2}{*}{ Coefficients } & \multicolumn{2}{|c|}{ Collinearity Statistics } \\
\hline & Tolerance & VIF \\
\hline $\mathrm{X}_{1}$ & .955 & 1.047 \\
\hline$X_{2}$ & .955 & 1.047 \\
\hline
\end{tabular}

Pegujian hipotesis sebagai berikut:

1. Hipotesis 1 berbunyi "Motivasi belajar $\left(\mathrm{X}_{1}\right)$ dan dukungan sosial $\left(\mathrm{X}_{2}\right)$ secara bersama-sama memiliki pengaruh yang signifikan terhadap hasil belajar matematika siswa kelas VIII SMP Negeri 2 Kusambi"

Hipotesis statistik:
$\mathrm{H}_{0}: \beta_{1}=\beta_{2}=0$; tidak ada pengaruh antara $\mathrm{X}_{1}, \mathrm{X}_{2}$ dengan $\mathrm{Y}$

$\mathrm{H}_{1}: \beta_{\mathrm{i}} \neq 0$; ada pengaruh antara $\mathrm{X}_{1}, \mathrm{X}_{2}$ dengan $Y$

di mana $\mathrm{i}=1,2$

Setelah dianalisis menggunakan IBM SPSS Statistic diperoleh tabel ANOVA seperti Tabel 3 berikut.

Tabel 3. Hasil Analisis Varians Regresi Variabel Motivasi Belajar dan Dukungan Sosial terhadap Hasil Belajar Matematika Siswa

\begin{tabular}{lrrrrr}
\hline \multicolumn{1}{c}{ Model } & Sum Of Squares & \multicolumn{1}{c}{ df } & Mean Square & F & Sig. \\
\hline Regression & 1370.032 & 2 & 685.016 & 11.671 & .000 \\
Residual & 3873.707 & 66 & 58.693 & & \\
Total & 5243.739 & 68 & & & \\
\hline
\end{tabular}

Dari tabel 3 diperoleh $\mathrm{F}_{\text {hitung }}=$ $11,671>\mathrm{F}_{\text {tabel }}=3,14$ atau nilai signifikan $0,000<\propto=0,05$, maka persamaan model regresi berarti dan linear, dengan $\mathrm{H}_{0}$ ditolak. Artinya terdapat pengaruh yang signifikan motivasi belajar dan dukungan sosial secara bersama-sama terhadap hasil belajar matematika siswa.

Persaman regresinya diperoleh dengan memperhatikan hasil analisis IBM SPSS Statistic pada tabel coefficients diperoleh $\hat{Y}=19,962+0,357 \mathrm{X}_{1}+$ $0,241 \mathrm{X}_{2}$. Koefisien Adjusted $\mathrm{R}^{2}=0,261 \times$ $100 \%$ atau $26,1 \%$ yang menunjukkan bahwa hasil belajar matematika siswa SMP Negeri 2 Kusambi dapat dijelaskan oleh motivasi belajar dan dukungan sosial secara bersama-sama sebesar 26,1\%, sisanya sisanya sebesar $73,9 \%$ dipengaruhi oleh faktor lain yang tidak diteliti dalam penelitian ini.

2. Hipotesis 2 berbunyi "Ada pengaruh yang signifikan motivasi belajar terhadap hasil belajar matematika siswa kelas VIII SMP Negeri 2 Kusambi”

Hipotesis statistik:

$\mathrm{H}_{0}: \beta_{1}=0$; tidak ada pengaruh antara $\mathrm{X}_{1}$ dengan $\mathrm{Y}$

$\mathrm{H}_{1}: \beta_{1} \neq 0$; ada pengaruh antara $\mathrm{X}_{1}$ dengan $\mathrm{Y}$

Setelah dianalisis menggunakan IBM SPSS Statistic diperoleh tabel Uji t seperti Tabel 4 berikut.

Tabel 4. Hasil Uji t Nilai Motivasi Belajar terhadap Hasil Belajar Matematika

\begin{tabular}{llrlrl}
\hline Model & \multicolumn{2}{l}{$\begin{array}{l}\text { Unstandardized } \\
\text { Coefficients }\end{array}$} & \multicolumn{3}{l}{$\begin{array}{l}\text { Standardized } \\
\text { Coefficients }\end{array}$} \\
\cline { 2 - 5 } & \multicolumn{1}{c}{ B } & Std. Error & Beta & \multicolumn{1}{c}{ t } & \multicolumn{1}{c}{ Sig. } \\
\hline (Constant) & 46.405 & 9.222 & & 5.032 & .000 \\
$X_{1}$ & .288 & .097 & .343 & 2.986 & .004 \\
\hline
\end{tabular}


Berdasarkan tabel 4 diketahui bahwa variabel motivasi belajar $\left(\mathrm{X}_{1}\right)$ memiliki sig. $=0,004<\propto=0,05$ atau thitung $=$ $2,986>t_{\text {tabel }}=1,99$ yang dipilih. Hal ini menunjukkan ditolaknya hipotesis $\mathrm{H}_{0}$, artinya Ada pengaruh yang signifikan motivasi belajar terhadap hasil belajar matematika siswa kelas VIII SMP Negeri 2 Kusambi. Persaman regresinya diperoleh dengan memperhatikan hasil analisis IBM SPSS Statistic pada tabel coefficients diperoleh $\widehat{Y}=46,405+0,288 \mathrm{X}_{1}$. Koefisien Adjusted $\mathrm{R}^{2}=0,117 \times 100 \%$ atau $11,7 \%$ yang menunjukkan bahwa hasil belajar matematika siswa SMP Negeri 2 Kusambi dapat dijelaskan oleh motivasi belajar sebesar $11,7 \%$, sisanya sisanya sebesar $88,3 \%$ dipengaruhi oleh faktor lain yang tidak diteliti dalam penelitian ini.

3. Hipotesis 3 berbunyi "Ada pengaruh signifikan dukungan sosial terhadap hasil belajar matematika siswa kelas VIII SMP Negeri 2 Kusambi”

\section{Hipotesis statistik:}

$\mathrm{H}_{0}: \beta_{2}=0$; tidak ada pengaruh antara $\mathrm{X}_{2}$ dengan $\mathrm{Y}$

$\mathrm{H}_{1}: \beta_{2} \neq 0$; ada pengaruh antara $\mathrm{X}_{2}$ dengan Y

Setelah dianalisis menggunakan IBM SPSS Statistic diperoleh tabel Uji t seperti tabel 5.

\begin{tabular}{|c|c|c|c|c|c|}
\hline \multirow[t]{2}{*}{ Model } & $\begin{array}{l}\text { Unstandard } \\
\text { Coefficients }\end{array}$ & & $\begin{array}{l}\text { Standardized } \\
\text { Coefficients }\end{array}$ & \multirow[b]{2}{*}{$\mathbf{t}$} & \multirow[b]{2}{*}{ Sig. } \\
\hline & B & $\begin{array}{c}\text { Std. } \\
\text { Error }\end{array}$ & Beta & & \\
\hline (Constant) & 58.478 & 6.068 & & 9.637 & .000 \\
\hline $\mathrm{X}_{2}$ & .186 & .073 & .298 & 2.558 & .013 \\
\hline
\end{tabular}

Berdasarkan tabel 5 diketahui bahwa variabel dukungan sosial $\left(\mathrm{X}_{2}\right)$ memiliki sig. $=0,013<\propto=0,05$ atau thitung $=$ $2,558>\mathrm{t}_{\text {tabel }}=1,99$ yang dipilih. Hal ini menunjukkan ditolaknya hipotesis $\mathrm{H}_{0}$, artinya Ada pengaruh yang signifikan dukungan sosial terhadap hasil belajar matematika siswa kelas VIII SMP Negeri 2 Kusambi. Persaman regresinya diperoleh dengan memperhatikan hasil analisis IBM SPSS Statistic pada tabel coefficients

\section{PEMBAHASAN}

Berdasarkan hasil analisis deskriptif motivasi belajar siswa kelas VIII semester genap SMP Negeri 2 Kusambi tahun ajaran 2017/2018 menunjukkan bahwa siswa yang motivasi belajarnya baik dan sangat baik mencapai $34,78 \%$ atau sebanyak 24 siswa dan siswa yang motivasi belajarnya masih kurang mencapai 65,22\% atau sebanyak 45 siswa. diperoleh $\widehat{Y}=58,478+0,186 \mathrm{X}_{1}$. Koefisien Adjusted $\mathrm{R}^{2}=0,089 \times 100 \%$ atau $8,9 \%$ yang menunjukkan bahwa hasil belajar matematika siswa SMP Negeri 2 Kusambi dapat dijelaskan oleh dukungan sosial sebesar 8,9\%, sisanya sisanya sebesar $91,1 \%$ dipengaruhi oleh faktor lain yang tidak diteliti dalam penelitian ini.

Masih kurangnya motivasi belajar siswa disebabkan oleh kurang ketekunan siswa dalam menghadapi tugas sekolah, kurangnya keuletan menghadapi kesulitan dalam kegiatan belajar di sekolah, tidak menunjukkan minat dalam belajar, kurang senang bekerja mandiri, cepat bosan pada tugas-tugas rutin di sekolah, tidak dapat mempertahankan pendapatnya, mudah 
melepas hal yang diyakini, serta kurang Senang mencari dan memecahkan masalah soal-soal matematika.

Berdasarkan hasil analisis deskriptif dukungan sosial siswa kelas VIII semester genap SMP Negeri 2 Kusambi menunjukkan bahwa siswa yang dukungan sosialnya baik dan sangat baik mencapai $33,33 \%$ atau sebanyak 23 siswa dan siswa yang dukungan sosialnya masih kurang mencapai $66,67 \%$ atau sebanyak 46 siswa. Hal ini disebabkan oleh kurangnya dukungan emosional (emosional support), dukungan penghargaan (esteem support), dukungan instrumental (instrumental support), dukungan informasi (information support) dan dukungan jaringan sosial (network support) siswa.

Berdasarkan hasil analisis deskriptif hasil belajar matematika siswa kelas VIII semester genap SMP Negeri 2 Kusambi menunjukkan bahwa siswa yang hasil belajarnya baik dan sangat baik mencapai $62,32 \%$ atau sebanyak 43 siswa, siswa yang hasil belajar matematikanya masih cukup mencapai 33,33\% atau sebanyak 23 siswa dan siswa yang hasil belajarnya masih kurang mencapai $4,35 \%$ atau sebanyak 3 siswa. Hal yang menyebabkan masih adanya nilai hasil belajar matematika siswa yang dibawah cukup karena kurangnya motivasi belajar dan dukungan sosial serta pengaruh faktorfaktor lain seperti faktor guru dan lingkungan sosial anak. Dari hasil analisis regresi linear ganda data motivasi belajar dan dukungan sosial siswa secara bersama-sama terhadap hasil belajar matematika siswa diperoleh persamaan regresi $\hat{Y}=19,962+0,357 \mathrm{X}_{1}+0,241 \mathrm{X}_{2}$ dengan koefisien determinasi $\mathrm{R}^{2}=0,261$. Setelah dilakukan uji keberartian dan kelinearan regresi diperoleh suatu kesimpulan bahwa persamaan regresi tersebut dapat dipergunakan untuk memperdiksi nilai hasil belajar matematika siswa jika nilai motivasi belajar dan dukungan sosial siswa secara bersama-sama diketahui.

Mengacu pada fungsi taksiran regresi linear ganda tersebut terlihat bahwa nilai konstanta sebesar 19,962 merupakan ramalan nilai hasil belajar matematika siswa tanpa ditunjang oleh motivasi belajar dan dukungan sosial siswa. Sedangkan koefisien arah regresi $\mathrm{X}_{1}$ sebesar 0,357 dan koefisien arah regresi $\mathrm{X}_{2}$ sebesar 0,241 yang menunjukkan hubungan yang positif dari motivasi belajar siswa maupun dukungan sosial siswa. Ini berarti bahwa hasil belajar matematika siswa (Y) dapat diperkirakan apabila motivasi belajar dan dukungan sosial siswa secara bersama-sama diketahui, yaitu setiap kenaikkan satu satuan nilai variabel motivasi belajar dan dukungan sosial akan diikuti kenaikkan nilai hasil belajar matematika siswa sebesar 0,357 satuan atas nilai motivasi belajar dan 0,241 satuan atas nilai dukungan sosial secara bersama-sama.

Nilai signifikansi antara motivasi belajar dan dukungan sosial terhadap hasil belajar matematika siswa lebih kecil dari $\propto=0,05$ yaitu sebesar 0,008 . Hal ini menunjukkan bahwa secara bersama-sama motivasi belajar dan dukungan sosial mempengaruhi hasil belajar matematika siswa.

Nilai koefisien determinasi $\left(\mathrm{R}^{2}\right)$ antara motivasi belajar dan dukungan sosial yaitu sebesar 0,261 menunjukkan bahwa motivasi belajar dan dukungan sosial siswa secara bersama-sama memberikan pengaruh yang cukup besar terhadap hasil belajar matematika siswa kelas VIII SMP Negeri 2 Kusambi dengan kontribusi sebesar $26,1 \%$ dan sisanya $73,9 \%$ merupakan kontribusi (sumbangan) dari variabel-variabel lain yang tidak dikaji dalam penelitian ini.

Secara teoritis, motivasi belajar dan dukungan sosial sangat mempengaruhi hasil belajar matematika siswa. Motivasi 
belajar pada dasarnya merupakan bagian dari motivasi secara umum. Dalam kegiatan belajar mengajar dikenal adanya motivasi belajar yaitu yang ada dalam dunia pendidikan atau motivasi yang dimiliki peserta didik (siswa). Belajar sangat diperlukan adanya motivasi dan hasil belajar akan menjadi optimal kalau ada motivasi. Makin tepat motivasi yang diberikan, akan makin berhasil pula pelajaran itu.

Dukungan sosial juga memegang peranan penting dalam upaya hasil belajar siswa. dukungan sosial dapat berupa pemberian informasi, bantuan tingkah laku, ataupun materi yang didapat dari hubungan sosial akrab yang dapat membuat individu merasa diperhatikan bernilai dan dicintai supaya dapat membantu belajar anak agar berjalan dengan baik.

Motivasi belajar dalam proses pembelajaran lebih besar sebagai kekuatan yang mendorong siswa untuk belajar. Siswa yang memiliki motivasi belajar dan dukungan sosial yang baik akan tampak terdorong terus untuk tekun belajar, mencurahkan semua perhatiannya, memanfaatkan setiap kesempatan untuk belajar matematika, serta meningkatkan keaktifan dan kedinamisan dalam belajar. Berbeda dengan siswa yang tidak mempunyai motivasi dan tidak mendapat dukungan sosial yang baik, mereka hanya tergerak untuk mau sekolah tetapi sulit untuk tekun belajar dan tidak mampu mengelolah pengalaman dan belajar secara terus menerus, dan cenderung menjadi siswa yang malas dan pasif dalam pembelajaran. Oleh sebab itu, untuk memperoleh hasil yang baik dalam belajar matematika seorang siswa harus mempunyai motivasi belajar yang bagus dan mendapat dukungan sosial sehingga akan mendorong ia untuk terus tekun belajar matematika yang pada akhirnya mencapai hasil belajar matematika yang optimal.
Berdasarkan hasil analisis regresi data motivasi belajar terhadap hasil belajar matematika siswa diperoleh persamaan regresi $\widehat{Y}=46,405+0,288 \mathrm{X}_{1}$ dengan koefisien determinasi $\mathrm{R}^{2}=0,117$. Mengacu pada fungsi taksiran ragresi linear tersebut terlihat bahwa nilai konstanta sebesar 46,405 merupakan ramalan nilai hasil belajar matematika siswa kelas VIII SMP Negeri 2 Kusambi tanpa ditunjang oleh nilai motivasi belajar siswa. Nilai koefisien variabel motivasi belajar siswa $\left(\mathrm{X}_{1}\right)$ yaitu sebesar 0,288, menunjukkan bahwa setiap perubahan satu satuan nilai motivasi belajar siswa pada pelajaran matematika kelas VIII SMP N 2 Kusambi menyebabkan bertambahnya hasil belajar matematika siswa sebesar 0,288 satuan. Setelah dilakukan uji keberartian (signifikan) dan kelinearan regresi diperoleh suatu kesimpulan bahwa persamaan regresi tersebut signifikan dan berpola linear atau dapat dipergunakan untuk memprediksi nilai hasil belajar matematika siswa kelas VIII SMP Negeri 2 Kusambi jika nilai motivasi belajar siswa diketahui.

Secara teoritis, motivasi belajar mempunyai peranan dalam melahirkan individu yang berciri keunggulan. Motivasi pada pembelajaran matematika merupakan salah satu faktor yang dapat mempengaruhi keberhasilan seseorang dalam proses pembelajaran. Motivasi penting karena mampu mendorong siswa untuk berhasil dalam belajar serta dapat menjadi individu yang tekun dan ulet . Siswa yang mempunyai motivasi dalam belajar matematika akan menimbulkan usaha yang gigih, serius dan tidak mudah putus asa untuk memperoleh hasil yang memuaskan. Jika seorang siswa memiliki rasa ingin belajar, ia akan cepat dapat mengerti dan mudah mengingatnya. Hal ini sejalan dengan hasil penelitian di kelas VIII SMP Negeri 2 Kusambi dimana nilai signifikan antara motivasi belajar terhadap hasil belajar matematika lebih kecil dari $\propto$ $=0,05$ yaitu sebesar 0,004. Hal ini 
menunjukkan bahwa secara parsial motivasi belajar mempengaruhi hasil belajar matematika siswa. Nilai koefisien determinasi $\mathrm{R}^{2}=0,117$ yang memberikan arti bahwa motivasi belajar memiliki pengaruh yang cukup besar terhadap hasil belajar matenmatika. Sedangkan untuk menyatakan besarnya kontribusi (sumbangan) variabel motivasi belajar $\left(\mathrm{X}_{1}\right)$ terhadap hasil belajar matematika $(\mathrm{Y})$ yaitu $\mathrm{R}^{2}$ X $100 \%=11,7 \%$ sedangkan sisanya $88,3 \%$ adalah merupakan kontribusi variabel-variabel lain yang tidak dikaji dalam penelitian ini.

Dari hasil analisis regresi data dukungan sosial terhadap hasil belajar matematika siswa diperoleh persamaan regresi $\hat{Y}=58,478+0,186 \mathrm{X}_{2}$ dan nilai koefisien determinasi $\mathrm{R}^{2}=0,089$. Mengacu pada fungsi taksiran regresi linear tersebut terlihat bahwa nilai konstanta sebesar 58,478 merupakan ramalan nilai hasil belajar matematika siswa tanpa ditunjang oleh nilai dukugan sosial.

Nilai koefisien variabel dukungan sosial $\left(\mathrm{X}_{2}\right)$ sebesar 0,186, menunjukkan bahwa setiap perubahan satu satuan nilai dukungan sosial menyebabkan bertambahnya nilai hasil belajar matematika siswa sebesar 0,186 satuan. Setelah dilakukan uji keberartian dan kelinearan regresi diperoleh suatu

\section{KESIMPULAN DAN SARAN}

Dari hasil analisis dan pembahasan diperoleh beberapa kesimpulan sebagai berikut:

1. Motivasi belajar siswa dalam kategori baik dan sangat baik sebanyak 34,78\% atau sebanyak 24 siswa dan yang kategori kurang sebanyak $65,22 \%$ atau sebanyak 45 siswa

2. Dukungan sosial siswa dalam kategori baik dan sangat baik sebanyak 33,33\% atau sebanyak 23 siswa dan yang kesimpulan bahwa persamaan regresi tersebut signifikan dan berpola linear atau dapat dipergunakan untuk memprediksi nilai hasil belajar matematika siswa jika nilai dukungan sosial diketahui.

Seperti halnya motivasi belajar, secara teoritis dukungan sosial juga merupakan salah satu faktor yang juga mempengaruhi keberhasilan belajar. Seorang siswa yang mendapat dukungan sosial yang baik maka akan memperlihatkan adanya kepatuhan dalam dirinya, mampu mengendalikan diri, konsentrasi dalam belajar, serta selalu siap untuk belajar.

Berdasarkan hasil penelitian di kelas VIII SMP Negeri 2 Kusambi dimana nilai signifikansi dukungan sosial terhadap hasil belajar matematika lebih kecil dari $\propto$ $=0,05$ yaitu sebesar 0.013. hal ini menunjukkan bahwa secara parsial dukungan sosial mempengaruhi hasil belajar matematika siswa. Nilai koefisien determinasi $R^{2}=0,089$, sedangkan untuk menyatakan besarnya kontribusi (sumbangan) variabel dukungan sosial $\left(\mathrm{X}_{2}\right)$ terhadap hasil belajar matematika $(\mathrm{Y})$ yaitu $\mathrm{R}^{2} \mathrm{x} 100 \%=8,9 \%$, hal ini memberikan arti bahwa dukungan sosial memiliki pengaruh yang kecil terhadap hasil belajar matematika.

kategori kurang sebanyak $66,67 \%$ atau sebanyak 46 siswa

3. Secara bersama-sama maupun terpisah motivasi belajar dan dukungan sosial berpengaruh terhadap hasil belajar matematika.

Dari pembahasan dan kesimpulan hasil penelitian, maka penulis menyarankan:

1. Motivasi belajar dan dukungan sosial siswa kelas VIII SMP Negeri 2 
Kusambi tahun pelajaran 2017/2018 dalam kategori sedang, untuk itu perlu ditingkatkan lagi agar hasil belajar yang diperoleh juga meningkat.

2. Bagi guru bidang studi harus selalu berusaha untuk meningkatkan kualitas atau kompetensi, baik secara pribadi maupun kelompok kerja, hal ini

\section{DAFTAR PUSTAKA}

Alma, Buchori, dkk. 2009. Guru Profesional Menguasai Metode dan Terampil Mengajar. Bandung: Alfabeta.

Appolo dan Cahyadi, Andi. 2012. Konflik Peran Ganda Perempuan Menikah yang Bekerja Ditinjau dari Dukungan Sosial Keluarga dan Penyesuaian Diri. Universitas Katolik Widya Mandala Madiun. Widya Warta, 02 (XXXVI): 254-271

Aqib, Zainal. 2013. Model-Model Media dan Strategi Pembelajaran Kontekstual (inovatif). Bandung: Yrama Widya.

Asmani, Ma'mur Jamal. 2009. JurusJurus Belajar Efektif Untuk SMP dan SMA. Jogjakarta: DIVA Press

Aunurrahman. 2016. Belajar dan Pembelajaran. Bandung: Alfabeta

Badan Standar Nasional Pendidikan. 2006. Standar Isi untuk Satuan Pendidikan Dasar dan Menengah. Jakarta: BSNP

Faturohman. 2007. Strategi Pembelajaran. Bandung: Insan Media

Hamzah, B. Uno dan Mohamad, Nurdin. 2014. Belajar dengan Pendekatan PAILKEM (Pembelajaran Aktif Inovatif Lingkungan Kreatif Efektif Menarik). Jakarta: Bumi Aksara

Isnawati, Dian dan Suhariadi, Fendy. 2013. Hubungan Antara Dukungan Sosial Dengan Penyesuaian Diri Masa Persiapan Pensiun Pada dimaksudkan agar proses pembelajaran agar dapat berjalan dengan baik, lebih menarik, inovatif, dan pada akhirnya kualitas pendidikan akan terus meningkat. Guru dianjurkan untuk tidak bosan dalam memberikan motivasi belajar terhadap peserta didiknya.

Karyawan PT Pupuk Kaltim. Universitas Airlangga. Jurnal Psikologi Industri dan Organisasi, 02 (1): $1-6$

Jihad. 2012. Evaluasi Pembelajaran. Yogyakarta: Multi Pressindo

Johnson, Doyle Paul. 1994. Teori Sosiologi Klasik dan Modern. Jakarta: Gramedia

King, A. Laura. 2012. Psikologi Umum (Sebuah Pandangan Apresiatif). Jakarta: Salemba Humanikia

Purba, Johana dkk. 2007. Pengaruh Dukungan Sosial Terhadap Burnout Pada Guru. Jurnal Psikologi, 5(1):77-87

Sardiman, A.M. 2016. Interaksi dan Motivasi Belajar Mengajar. Jakarta: Rajawali Persada 